\title{
2012- 2013 Yılında 60-66 Ay Arasında Ve 66 Ay Üzerinde Birinci Sınıfa Başlamış Beşinci Sınıf Öğrencilerinin Sosyal Uyum Düzeyleri Ve Benlik Saygılarının Karşılaştırılması*
}

\section{Comparison of Social Adaptation and Self-Esteem of the 5th Grade Students Who Started the 1st Class in the Period of 2012-2013 Between 60-66 Months and Over 66 Months}

\author{
Dr. Öğr. Üyesi Alper Çuhadaroğlu ${ }^{1}$, Rehber Öğretmen Sevda ÇELIK ${ }^{2}$
}

\begin{abstract}
Özet
Araştırmanın amacı ilkokula başlama yaşının 5. Sınıftaki öğrencilerin benlik saygısı ve sosyal uyum düzeyleri ile ilişkisini incelmektir. Ayrıca bazı demografik değişkenlerin (cinsiyet, kardeş sayısı, anne baba eğitim düzeyi, anne- baba birliktelik durumu, anaokuluna devam durumu ve ilkokulda öğretmen değişikliği yaşayıp yaşamama durumu) sosyal uyum ve benlik saygısı arasındaki ilişkiler incelenmiştir. Bunun için İstanbul ili Kartal ilçesindeki 26 Ortaokulda 436 5. sınıf öğrencisine Walker-McCannell Okula Uyum ve Sosyal Yeterlik Ölçeği, Coopersmith Özsaygı Envanteri Kısa Formu ile amaca uygun olarak düzenlenmiş Demografik Bilgi Formu uygulanmıştır. Verilerin analizinde Bağımsız Örneklem T Testi, Pearson Korelasyon Analizi ve Tek Yönlü Varyans Analizi (ANOVA) yapılmıştır. Araştırmadan elde edilen bulgulara göre, öğrencilerin benlik saygılarının ve sosyal uyum düzeylerinin, okula başlama yaşına göre anlamlı bir şekilde farklılaşmadığı saptanmıştır. Ayrıca, kız öğrencilerin benlik saygılarının erkek öğrencilerden anlamlı bir şekilde daha yüksek olduğu; anne - babası birlikte yaşayan öğrencilerin benlik saygılarının anne - babası ayrı olanlardan daha yüksek olduğu saptanmıştır.
\end{abstract}

Anahtar Kelimeler: Okula başlama yaşı, benlik saygısı, sosyal uyum

Makale Türü: Araştırma makalesi

\begin{abstract}
The main purpose of the study is to examine the effects of the primary school starting age on the selfesteem and social adjustment levels of students of the 5th grade. In addition, the relationships between some demographic variables (gender, number of siblings, parental education level, parental status, attendance at kindergarten, and teacher change in primary school) and social adjustment and selfesteem were examined. Walker-McCannell Adaptation to School and Social Skills Scale, Coopersmith Self-Esteem Inventory Short Form and appropriately arranged Demographic Information Form applied to 4365 th grade students in Kartal district. Independent Sample T-Test, Pearson Correlation Analysis and One-Way ANOVA were used to analyse collected data. According to the results, there is no significant relationship neither between the age to start school and self-esteem nor between social adjustment. The self-esteem of female students is significantly higher than males and the self-esteem of students whose parents are together have higher self-esteem than the students that
\end{abstract}

\footnotetext{
* Bu çalışma, Maltepe Üniversitesi Sosyal Bilimler Enstitüsünde sunulmuş olan yüksek lisans tez çalışmasınndan üretilmiştir.

${ }^{1}$ Maltepe Üniversitesi, Eğitim Fakültesi, alpercuhadaroglu @ maltepe.edu.tr, Orcid ID: https://orcid.org/0000-0001-5715-0024

2 Kartal Milli Eğitim Vakfi Ortaokulu, sevda.celik37@gmail.com, Orcid ID: https://orcid.org/0000-0002-1679-0938 

2012-2013 Between 60-66 Months and Over 66 Months

have divorced parents. It is also found that, there are significant relationship between education levels of children's parents, number of siblings and self-esteem. Another significant difference is detected between number of siblings and children's social adaptation.

Key words: School starting age, self-esteem, social adaptation

Paper Type: Research paper

\section{Giriş}

2012- 2013 Eğitim öğretim y1lında, Türkiye'de eğitim sisteminde önemli değişiklikler yapılarak 8 yıllık zorunlu eğitim 4 yıl ilkokul, 4 yıl ortaokul ve 4 yıl lise olarak toplam 12 yıla çıkarılmış ve okula başlama yaşı 72 aydan 60 aya düşürülmüştür (İlköğretim ve Eğitim Kanunu [İEK], 2012). Aynı yıl bazı okullarda hem 60-66 aylık çocuklar hem de 66 aylık ve üstü çocuklar aynı sınıfta eğitim görmeye başlamışlardır. Daha sonra ilgili yönetmelikte değişiklik yapılarak, ilkokula zorunlu başlama yaşı o yıl eylül ayında 66 ayını doldurma şartı ile değiştirilmiştir. 60 aylık çocuklar ise veli isteği ile kayıt yaptırılması ve 66 ayını doldurduğu halde okula göndermek istemeyen velilerin, doktor raporu ile ilkokula kaydını bir yıl erteleyebileceği şeklinde değiştirilmiştir (Millî Eğitim Bakanlığı [MEB], 2014).

Araştırma kapsamında okula başlama yaşının etkileri konusunda yapılan alanyazın taramasında, okula başlama yaşı ile akademik başarı (Crosser, 1991; Kawaguchi, 2011; Cascio ve Schanzenbach, 2016; Gürsakal, 2012), sosyal uyum (Dirlik, 2014), akademik erteleme (Cameron \& Wilson, 1990), çocuğun ilerdeki toplam eğitim süresi (Angrist ve Krueger, 1992; Black, Devereux, \& Salvanes, 2011), okula hazırbulunuşluk düzeyi (Kahrmanoğlu, Tiryaki ve Canpolat, 2014) ve okul olgunluğu (Gündüz ve Çalışkan, 2013; Tutal, 2013; Bayat, 2015) konularında çalışmalar yapıldığı görülmüştür. Bu konuda Tükiye'de yapılan araştırma sonuçlarının büyük bir kısmında erken okula başlama yaşının (60-66 ay) olumsuz etkilerinin vurgulandığı görülmüştür (Tutal, 2013; Gündüz ve Çalışkan, 2013; Dirlik, 2014; Durna, 2014; Kahrmanoğlu, Tiryaki ve Canpolat, 2014; Merter, Şekerci ve Bozkurt, 2014; Bayat, 2015; Kartal, Bolattekin ve Bilgin 2016).

$\mathrm{Bu}$ araştırma sonuçları incelendiğinde, 1990 yılında ABD'de yapılan bir araştırmada, okula başlama yaşı ile akademik erteleme, okulu dondurma ve okuldan bir yıl uzaklaşma arasındaki ilişki araştırılmış, okula erken ve geç başlayanların bilişsel yetenek puanları arasında anlamlı bir fark bulunmuş, ayrıca geç başlamanın okuldan uzaklaşma konusunda bir avantaj sağlamadığ 1 sonucuna ulaşılmıştır (Cameron \& Wilson, 1990).

Crosser (1991) 5 ve 6 yaşında okula başlayan çocukların akademik başarılarını karşılaştırdığ 1 araştırmada, 6 yaşında anaokuluna başlayan çocukların 5 yaşında başlayanlara göre akademik olarak daha avantajlı olduğu sonucuna ulaşmıştır.

Angrist ve Krueger (1992), okula başlama yaşının etkileri konusunda daha önce yapılan araştırmalarda sadece giriş yaşının dikkate alınmasını eksiklik olarak değerlendirmişler ve okula giriş yaşları ile eğitim süreleri arasındaki ilişkiyi araştırmışlardır. Sonuçta okula geç başlayan katılımcıların eğitim hayatlarının erken başlayanlara göre daha kısa sürdüğü sonucuna ulaşmışlardır. 
Yavuzer'e (2004) göre çocuğun okul olgunluğuna ulaşmadan erken yaşta birinci sınıfa başlatılması hatadır. Ona göre Bazı batılı ülkelerde eğitim programı uygun bir şekilde yapılandırıldığından 5 yaşında okula başlamalarının zararı olmamaktadır. Fakat Türkiye'de eğitim programı düzenlenmeden, öğretmenler buna uygun olarak eğitilmeden çocukların okula erken başlatılması ile okul fobisine, psikosomatik rahatsızlıklara ve bunun gibi pek çok sorun yaşanmasına neden olmaktadır (Yavuzer, 2004).

Grissom (2004), okula geç başlayanların erken başlayanlara göre daha avantajlı olabileceği hipotezini test etmeyi hedeflediği araştırmasında, ilkokulda okula başlama yaşı ile akademik başarı arasında pozitif ve doğrusal ilişki olmasına rağmen, geç başlayanlar ile erken başlayanların test puanlarındaki farkın çok büyük olmadığı, aynı zamanda öğrenciler 10 . Sınıfa ulaştıklarında bu pozitif ve doğrusal ilişkinin kaybolduğu sonucuna ulaşmıştır.

Japonya'da yapılan bir araştırmada, çocukların yılda bir kez nisan ayında öğrenci alınmasının sonucu olarak çocukların doğum tarihine bağlı olarak farklı yaşlarda okula başlamalarının (yani nisan ayında 6 yaşını doldurmuş olan çocukların okula girdiği varsayılırsa, mart ayında doğan çocuk ile nisan ayında doğan çocuk arasında neredeyse 1 yaş fark olması) eğitim başarılarına etkisi araştırılmıştır. Araştırma sonucunda, nisan ve haziran ayları arasında doğan çocukların, ocak ve mart ayları arasında doğanlara göre daha fazla başarıya sahip oldukları bulunmuştur (Kawaguchi, 2011).

2011 yılında Norveç'te yapılan bir çalışmada, okula erken ve geç başlamanın 18 yaşından sonraki etkileri kıyaslandığında, geç başlamanın olumlu etkilerinin daha fazla olduğu, geç başlamanın eğitim düzeyi üzerinde küçük bir etkisi olduğu sonuçlarına ulaşımış ve geç başlamanın olumsuz etkisi olarak da erken hamilelik riskinden bahsetmişlerdir. (Black, Devereux, \& Salvanes, 2011).

Gürsakal (2012), 2000 y1lından beri her üç yılda bir tekrarlanan 'Uluslararas1 Öğrenci Değerlendirme Programı' olarak da bilinen PISA araştırma raporuna dayanarak yaptığı araştırmaya göre, okula başlama yaşı arttıkça akademik başarı düşmektedir.

Gündüz ve Çalışkan'ın (2013) çocukların yaş gruplarına göre okul olgunluk düzeylerini araştırdıkları çalışmada, okul olgunluk düzeyi ile okula başlama yaşı arasında anlamlı fark bulunmuş ve 72- 84 aylık çocukların okul olgunluk düzeylerinin hem 66-72 hem de 60-66 aylık çocuklardan anlamlı derecede yüksek olduğu sonucuna ulaşmışlardır.

İlkokul başlama yaşının okuma başarısına etkisinin araştırıldığı bir araştırmada, 60-66 aylık çocuklar ve 72 ay üstü çocuklar ilk okuma, yazma ve okuduğunu anlama konularında 72 aylık ve üstü çocukların 60- 66 aylık çocuklardan daha başarılı oldukları sonucuna ulaşmışlardır (Tutal, 2013).

Araştırma kapsamındaki bir diğer konu ise sosyal uyum konusudur. Sosyal uyum, bireyin çevresine adapte olması şeklinde tanımlanabilir (Kalyencioğlu ve Kutlu, 2010; Serebryakova, Morozova, Kochneva, Zharova, Skitnevskaya \& Kostina, 2016). Çocuğun akranları ile kurduğu ilişki biçimi onun sosyal uyumunu gösterir (Iş̧1k, 2007). Bireyin yaşadığı çevreyi tanıması, kurallara uyum sağlaması, olumlu iletişim kurması ve ilişkilerinin sağlam ve kaliteli olması sosyal uyumu ile bağlantılıdır (Kurt, 2007). Dolayısıyla bireyin çevresine uyum sağlayabilmesi için iletişim becerilerine, kişiler arası ilişki becerilerine ve kendini gerçekleştirme becerilerine sahip olması gerekmektedir (Tapmaz, 2012). Nitekim 

2012-2013 Between 60-66 Months and Over 66 Months

Kapçı, Artar, Avşar, Daşçı ve Çelik (2015) gerçekleştirdikleri bir çalışmada beş yaşındaki çocukların altı yaşındaki çocuklara oranla daha yüksek düzeyde duygusal, davranışsal ve sosyal sorunlar yaşadıklarını, akademik benlik algılarının ise daha düşük olduğunu saptamışlardır.

Son olarak araştırma kapsamında benlik saygısı konusuna yer verilmiştir. Benlik kavramının bileşenlerinden biri olan benlik saygısı, benliğin duygusal yönüdür (Berk, 2013). Benlik saygısı insanın kendine verdiği değer derecesidir (Baumeister, Campbell, Krueger \& Vohs, 2003). Benlik saygısı, bireyin kendini değerli görmesi ve sevilmeye değer bir varlık olarak görmesidir (Oktan ve Şahin, 2010; Yavuzer, 2003). Yani benlik sayg1s1, bireyin kendisinden hoşnutluk düzeyidir (Seçer, İlbay, Ay \& Çiftçi, 2012). Benlik saygısı hakkında yerleşen yanlış düşüncelerden biri 'başkalarının zararı pahasına da olsa kendini iyi hissetme halidir. $\mathrm{Bu}$ düşünce sağliklı benlik saygısını ifade etmediği gibi, bu şekilde davranan bireylerin benlik saygılarının çok düşük olduğu ve bu durumu telafi etmek adına bu şekilde davrandığı düşünülebilir (Plummer, 2011). Baumeister ve arkadaşlarına (2003) göre, benlik saygısı gerçeklikten çok algıya dayanır ve bazen insanlar gerçeklikle baş edemediklerinde iyi olduklarını düşünmeyi tercih edebilirler. Ve benlik saygısı asla bir amaç olmamalıdır, temelinde ahlaklı davranmak olmalıdır. Çocuklara yapılan yersiz övgüler narsizmi körüklemektedir. Çocuğun olumsuz davranışları benlik saygısını azaltacağından endişe edilmeden eleştirilebilmesi gereklidir (Baumesiter ve ark., 2003).

Sonuç olarak alanyazındaki çalışmalar göz önüne alındığında, okula erken başlayan ve geç başlayan çocuklar arasında gelişimsel farklılıklar olması beklenmektedir (Huges, Pinkerton \& Plewis, 1979; Langer, Kalk \& Searls, 1984; Crosser, 1991; Datar, 2006; Kawaguchi, 2011; Merter, Şekerci, \& Bozkurt, 2014; Durna, 2014; Kahramanoğlu, Tiryaki, \& Canpolat, 2014; Bayat, 2015 ). Gelişimin bir bütün olduğu ilkesini göz önüne alındığında; erken başlayan çocuklar, geç başlayan çocuklardan herhangi bir gelişim alanında geri kaldığında bu durum diğer gelişim alanlarını da etkileyecektir. Bu durumun, aynı sınıfta ortalama 9-12 aylık fark olan çocuklar arasında, erken başlayan çocukların sosyal uyum düzeyleri ve benlik saygı düzeyleri açısından dezavantaj olacağı düşünülmektedir. Mevcut araştırmada bu dezavantajın ortaokul dönemine aktarılıp aktarılmadığı araştırılmıştır.

\section{YÖNTEM}

\subsection{Evren ve Örneklem}

Araştırmanın evrenini İstanbul'daki tüm beşinci sınıf öğrencilerinden birinci sınıfa 60- 66 ay arasında başlayanlar ile 67 ay üzerinde başlayanlar oluşturmaktadır. İstanbul'un Kartal ilçesindeki tüm 5 sınıf öğrencileri doğum tarihlerine göre iki gruba ayrıldıktan sonra, her iki alt grubun içinden rastgele yöntemle seçilen öğrenciler de araştırmanın örneklemini oluşturmaktadır. Bu süreçte oranlı eleman örnekleme yöntemi kullanılmıştır. Oranlı eleman örnekleme yönteminde evrendeki tüm elemanlar ortak özelliklerine göre alt evrene ayrılır. $\mathrm{Bu}$ ayrılan alt evrendeki tüm elemanların hepsi eşit olarak seçilme şansına sahip olur. Her bir alt evrenden alınacak miktar, o alt everenin bütün evren içindeki oranı kadar alınarak örneklemin evreni temsil düzeyi güvence altına alınmış olur (Karasar, 2014). 60-66 aylık birinci sınıfa başlamış olan 639 öğrenciden okul numarası tek sayı olan 323 beşinci sınıf öğrencisi ile 67 ve daha üstü aylık birinci sınıfa başlamış olan 5157 öğrenciden okul numarası 5 ve 5 'in katı olan 923 beşinci sınıf öğrencisi seçilmiştir. (Toplam 1309 öğrenci). 
Okul rehber öğretmenleri aracılığıyla 1309 öğrencinin velisine araştırma onay formu gönderilmiş ve 436 veli öğrencisinin araştırmaya katılmasına izin vermiştir. Buna göre araştırmanın örneklemini $219 \mathrm{kız}, 217$ erkek öğrenci olmak üzere toplam 436 öğrenci yer almaktadır. Bu öğrencilerden 97'si 60-66 aylıkken birinci sınıfa başlamış, 339'u 67 aylık ve daha büyükken birinci Sınıfa başlamıştır.

\subsection{Veri Toplama Araçları}

\subsubsection{Bilgi ve Onay Formu}

Araştırmaya katılan öğrencilerin velileri için yapılan çalışma ile ilgili bilgilendirilmesini ve velilerin onayları doğrultusunda çalışmanın yapılması için onay formu hazırlanmıştır.

\subsubsection{Sosyo-demografik Bilgi Formu}

Öğrencinin demografik özellikleri hakkında bilgi edinmek amacıyla demografik bilgi formu oluşturulmuştur. Sosyo-demografik bilgi formunda öğrencilerin okulları, sınıfları, doğum tarihleri, cinsiyetleri, anne- babalarının eğitim derecesi, kardeş sayıları, anne- babalarının birlikte olup olmadıkları, okul öncesi kuruma devam edip etmedikleri ve ilkokulda öğretmen değişikliği yaşayıp yaşamadıkları sorulmuştur.

\subsubsection{Walker-McConnell Sosyal Yeterlik ve Okul Uyum Ölçeği (WMC-SYOUÖ)}

Ölçek, Walker ile McConnel (1995) tarafından ergenler ve ilköğretim öğrencilerinin sosyal uyum becerilerini ölçmek için iki ayrı format olarak geliştirilmiştir (Akt. Aysan ve Uz Baş, 2004). İlköğretim öğrencilerine yönelik olarak hazırlanan Walker-McConnell Sosyal Yeterlik ve Okul Uyum Ölçeği ilköğretim versiyonu, 5'li likert tipindedir 3 alt ölçekten oluşmaktadır. Bu alt ölçekler, öğretmen tercihli sosyal davranış, akran tercihli sosyal davranış ve okula uyum davranışlarıdır (Aysan ve Uz Baş, 2004). Öğretmen tercihli sosyal davranış alt ölçeğinde, öğretmenin gözüyle öğrencinin akranları arasındaki davranışlarından empati, iş birliği ve özdenetim davranışlarını ölçmektedir. Akran tercihli sosyal davranış alt ölçeğinde, öğrencinin serbest oyun zamanında akranlarına yönelik davranışları ölçülmektedir. Okula uyum davranışları alt ölçeğinde ise öğretmenin gözünde öğrencinin eğitim ortamına ilişkin sosyal davranışlarını ölçmektedir (Uz Baş, 2003).

Ölçeğin standartizasyon çalışmaları ABD'nin 4 eyaletinden 2000 öğrenci ile yapılmıştır. Her bir maddenin puanı 1-5 aralığında olup tüm maddelerin puanlarının toplamı ile ölçeğin toplam puanı elde edilmektedir (Uz Baş, 2003).

Walker -McConnel (1995) ölçeğin yapı geçerliğine ilişkin yaptığı çalışmada, Crombach Alfa katsayısını Öğretmen Tercihli Sosyal Davranış alt ölçeğinde 0,96, Akran Tercihli Sosyal Davranış Alt Ölçeğinde 0,95, Okula Uyum alt ölçeğinde 0,96 ve ölçeğin toplamında 0,97 olduğu sonucuna ulaşmışlardır (Akt. Kabasakal ve Çelik, 2010).

Ölçeğin Türkiye'deki geçerlik ve güvenirlik çalışması Uz Baş (2003) tarafindan yapılan çalışmada ölçeğin Crombach Alfa iç tutarlılık katsayıları Öğretmen tercihli sosyal davranış alt ölçeğinde $r=0,80$, akran tercihli sosyal davranış alt ölçeğinde $r=0,85$, okula uyum davranışı alt ölçeğinde $r=0,87$ ve toplam iç tutarlılık katsayısı ise $r=0,85$ olduğu 
sonucuna ulaşılmıştır. Ayrıca bu çalışmada ölçeğin Cronbach Alpha katsayısı 0,98 olarak hesaplanmıştır.

Ölçekteki sosyo-demografik bilgi kısmında ad soyadı bilgisi yer aldığından İstanbul Il Milli Eğitim Müdürlüğü araştırma komisyonu tarafından çıkarılması istenmiş ve ölçekteki bu kısım çıkarıldıktan sonra komisyon tarafından onaylanmıştır.

\subsubsection{Coopersmith Özsaygı Envanteri}

Ölçek, Stanley Coopersmith (1986) tarafindan geliştirildikten sonra, yapılan revize çalışmalarından sonra 3 formu geliştirilmiştir. (Yetişkin Formu, Okul Formu ve Okul Kısa Formu) Araştırmada Coopersmith Öz Saygı Envanteri Okul Kısa Formu kullanılmıştır. Okul Kısa Formu 25 maddeden oluşmaktadır. Alt ölçekleri olmadığı için genel bir puan elde edilmektedir. Ölçek soruları evet hayır diye cevaplanmakta ve her maddenin 4 puanı vardır ve ölçekten toplam 100 puan elde edilmektedir. (Akt. Pişkin, 1996).

Ölçeğin Türkçe’ye çevirisini ve geçerlik güvenirlik çalışmasını ilk olarak Özoğul (1998) yapmış, daha sonra Coopersmith Özsaygı Envanterinin geçerlik güvenirlik çalışması Gürçay (1989) tarafından yapılmıştır (Akt. Pişkin, 1997). Ancak yukarda bahsedilen her iki araştırmacı da ölçeğin geçerlik ve güvenirlik çalışmalarını ilköğretim öğrencilerine uyguladığı ve lise öğrencileriyle uygulama yapılarak geçerlik güvenirlik çalışmalarının yapılması gerektiği düşüncesi ile Pişkin (1997), 151 İngiliz ve 315 Türk öğrenciye uygulayarak ölçeğin geçerlik güvenirlik çalışmalarını yapmış ve ölçeğin kısa formu için KR21 katsayısını 0,83 olarak hesaplamıştır. Ayrıca bu çalışmada da ölçeğin Cronbach Alpha katsayısı 0,79 olarak hesaplanmıştır.

\subsection{Verilerin Toplanması}

Araştırmanın verileri 2016 - 2017 öğretim yılının bahar yarıyılında gerçekleştirilen çalışmayla toplanmıştır. Araştırmaya katılmayı kabul eden velilerin çocuklarının öğretmenlerine, Walker-McConnell Sosyal Yeterlik ve Okul Uyum Ölçeği uygulanacağ öğretmenlere ölçek ile ilgili bilgi verilmiştir. Daha sonra, ilgili okullarda araştırmac1 tarafından öğrencilere Coopersmith Özsaygı Envanteri ve öğrencilerin öğretmenlerine Walker-McConnell Sosyal Yeterlik ve Okul Uyum Ölçeği uygulanmıştır. Uygulanan ölçekler toplandıktan sonra uygulamadan toplanan veriler Statistical Package for Social Sciences (SPSS) versiyon 15 programı kullanılarak bilgisayar ortamına aktarılmıştır.

\subsection{Verilerin Analizi}

Araştırmada elde edilen bulgular incelenirken SPSS ver. 15 programı kullanılmıştır. Öncelikli olarak araştırmadan elde edilen verilerin normal dağılım varsayımını karşılayıp karşılamadığını saptama amacıyla normallik testleri gerçekleştirilmiş ve dağılımların normal olduğu görüşmüştür ( $>$ > 0,05). Ayrıca verilerin analizinde Bağımsız Örneklem T-Testi, Pearson Korelasyon Analizi ve Tek Yönlü Varyans Analizi (ANOVA) kullanılmıştır.

Birinci sınıfa erken başlayan ve geç başlayan grupların ölçek puanları (sosyal uyum puanı ve benlik saygısı puanı) arasında anlamlı bir fark olup olmadığına bakılırken Bağımsız Örneklem T-Testi (İndepented- Samples T-Test) kullanılmıştır. 
Öğrencilerin benlik saygısı puanları ile sosyal uyum ölçeği alt ölçekleri puanları ve toplam puanları arasında anlamlı bir ilişki olmadığına bakılırken, Pearson Korelasyon Analizi yapılmıştır.

Öğrencilerin benlik saygısı puanları ve sosyal uyum puanları ile sosyo-demografik değişkenler (cinsiyet, kardeş sayısı, anne baba eğitim düzeyi, anne- baba birliktelik durumu, anaokuluna devam durumu ve ilkokulda öğretmen değişikliği yaşayıp yaşamama durumu) arasındaki ilişkiye bakılırken Bağımsız Örneklem T- Testi (İndepented- Samples T-Test) ve Tek Yönlü Varyans Analizi (ANOVA) yapılmıştır.

\section{Bulgular}

60-66 ay ile 67 ve üzerinde birinci sınıfa başlamış beşinci sınıf öğrencilerinin sosyal uyum düzeyleri arasında anlamlı bir farklılaşma olup olmadığını saptama amacıyla bağımsız örneklem T-Testi yapılmış ve analiz sonuçları Tablo 1'de verilmiştir.

Tablo 1. 60-66 ay arasında ve 67 ay ve üzerinde birinci sınıfa başlamış beşinci sınıf öğrencilerinin toplam sosyal uyum puanlarının bağımsız örneklem t- testi sonuçları

\begin{tabular}{|c|c|c|c|c|c|}
\hline Okula Başlama Yaşı & $\mathrm{N}$ & Ort & Ss & $\mathrm{t}$ & $\mathrm{p}$ \\
\hline 60-66 Аy & 97 & 156,4227 & 38,71526 & \multirow[t]{2}{*}{0,653} & \multirow[t]{2}{*}{0,514} \\
\hline 67 Ay ve Üzeri & 339 & 153,4346 & 40,07941 & & \\
\hline
\end{tabular}

Tablo 1'deki veriler incelendiğinde araştırmaya katılan öğrencilerden 60- 66 ay arasında 1. Sınıfa başlamış olanlar ile 67 ay ve üzerinde 1 . Sınıfa başlamış olanların, sosyal uyum düzeyleri arasında istatistiksel olarak anlamlı bir fark olmadığ 1 görülmüştür. ( $t=0,653$ p> 0.05). 60-66 ay ile 67 ve üzerinde 1. sınıfa başlamış 5. Sınıf öğrencilerinin benlik saygısı düzeyleri arasında anlamlı bir farklılaşma olup olmadığını saptama amacıyla bağımsız örneklem T-Testi yapılmış ve analiz sonuçları Tablo 2'de verilmiştir.

Tablo 2. 60-66 ay arasında ve 67 ay ve üzerinde birinci sınıfa başlamış beşinci sınıf

öğrencilerinin toplam benlik saygısı puanlarının bağımsız örneklem t- testi sonuçları

\begin{tabular}{|c|c|c|c|c|c|}
\hline & $\mathrm{N}$ & Ort & $\mathrm{Ss}$ & $\mathrm{t}$ & $\mathrm{p}$ \\
\cline { 1 - 4 } $600-66$ Ay & 97 & 70,5979 & 16,74357 & $-1,033$ & 0,302 \\
\cline { 1 - 4 } 67 Ay ve Üzeri & 339 & 73,6342 & 17,23014 & & \\
\hline
\end{tabular}

Araştırmaya katılan öğrencilerden 60- 66 ay arasında 1. Sınıfa başlamış olanlar ile 67 ay ve üzerinde 1 . Sınıfa başlamış olanların, benlik saygısı toplam puanları arasında istatistiksel olarak anlamlı bir fark olmadığ görülmüştür. $(\mathrm{t}=-1,033 \mathrm{p}>0,05)$

Öğrencilerin benlik saygısı ve sosyal uyum düzeyleri arasında anlamlı bir ilişki olup olmadığını saptama amacıyla Pearson Korelasyon Analizi yapılmış ve sonuçlar Tablo- 3'te verilmiştir. 

2012-2013 Between 60-66 Months and Over 66 Months

Tablo 3. Öğrencilerinin benlik saygısı ile sosyal uyum düzeyleri ilişkisine ilişkin korelasyon analizi sonuçları

\begin{tabular}{|c|c|c|c|c|c|}
\hline & $\mathrm{N}$ & Ort. & Ss & $\mathrm{r}$ & $\mathrm{p}$ \\
\cline { 1 - 5 } Benlik Saygis1 & 436 & 72,1812 & 17,12501 & \multirow{2}{*}{0,267} & 0,00 \\
\cline { 1 - 5 } Sosyal Uyum & 436 & 154,0986 & 39,75542 & & \\
\hline
\end{tabular}

Benlik saygısı toplam puanı ve sosyal uyum toplam puanı arasındaki ilişkiyi belirlemek için Pearson Korelasyon Analizi yapılmış ve benlik saygısı ile sosyal uyum düzeyi arasında pozitif yönlü ve anlamlı bir ilişki olduğu görülmüştür. $(r=0,267, p<0,05$, ). Yani öğrencilerin benlik saygısı puanı arttıkça sosyal uyum puanı da artmaktadır.

Sosyal uyum ile sosyo-demografik değiş̧kenler (Cinsiyet, anne- baba eğitim derecesi, kardeş sayısı, anne baba birliktelik durumu, okul öncesi eğitim durumu ve ilkokulda öğretmen değiş̧ikliği yaşayıp yaşamama durumu) arasındaki ilişkiye bakılırken Bağımsız Örneklem T Testi ve Tek Yönlü Varyans Analizi yapılmış ve analiz sonuçları Tablo-4, Tablo-5, Tablo-6, Tablo-7, Tablo-8, Tablo-9 ve Tablo-10'da verilmiştir.

Tablo 4. Öğrencilerin cinsiyetleri ile sosyal uyum toplam puanlarının bağımsız örneklem t testi sonuçları

\begin{tabular}{|l|c|c|c|c|c|}
\hline & N & Ort & Ss & t & $p$ \\
\hline K1z & 219 & 162.7477 & 38.74846 & 4,596 & 0,000 \\
\hline Erkek & 217 & 145.6267 & 38.94445 & & \\
\hline
\end{tabular}

Araştırmaya katılan öğrencilerin cinsiyetlerine göre toplam sosyal uyum puanlarının anlamlı bir farklılık gösterip göstermediğini saptama amacıyla Bağımsız Örneklem T-Testi yapılmış ve iki grup ortalamaları arasında istatistiksel olarak anlamlı bir fark olduğu görülmüştür $(\mathrm{t}=4,596 \mathrm{p}<0,05)$. Ortalamalar arasındaki farka bakıldığında kız öğrencilerin toplam sosyal uyum puan ortalamalarının erkek öğrencilerin puanından daha yüksek olduğu görülmüştür $(162,7477>145,6267)$. Bu sonuca göre k1z öğrencilerin sosyal uyum düzeylerinin erkek öğrencilerden anlamlı ölçüde yüksek olduğu görülmektedir.

Tablo 5. Öğrencilerin anne eğitim dereceleri ile toplam sosyal uyum puanlarının tek yönlü varyans analizi (ANOVA) sonuçları

\begin{tabular}{|c|c|c|c|c|c|c|c|c|c|}
\hline $\begin{array}{c}\text { Anne E. } \\
\text { D. }\end{array}$ & $\mathrm{N}$ & Ort & Ss & $\begin{array}{c}\text { Varyans } \\
\text { K. }\end{array}$ & K. T. & sd & K. O. & F & p \\
\hline $\begin{array}{c}\text { Okuma- } \\
\text { Yazma } \\
\text { Bil }\end{array}$ & 20 & 144,7500 & 40,84228 & G. Aras1 & 4751,586 & 4 & 1187,896 & 0,750 & 0.558 \\
\hline Ilkokul & 134 & 152,6567 & 41,05051 & G. İçi & 682763,2 & 431 & 1584,137 & & \\
\hline Ortaokul & 104 & 151,8750 & 35,67618 & Toplam & 687514,8 & 435 & & & \\
\hline Lise & 56 & 157,0000 & 41,31396 & & & & & & \\
\hline $\begin{array}{c}\text { Lisans ve } \\
\text { Üstü }\end{array}$ & 436 & 158,6964 & 40,29885 & & & & & & \\
\hline
\end{tabular}

Araştırmaya katılan öğrencilerin annelerinin eğitim düzeylerine göre toplam sosyal uyum puanlarının anlamlı bir farklılık gösterip göstermediğini saptama amaciyla Tek Yönlü Varyans Analizi (ANOVA) yapılmış ve iki grup ortalamaları arasında istatistiksel olarak anlamlı bir fark olmadığ görülmüştür $(\mathrm{f}=0,750 \mathrm{p}>0,05)$. 
Tablo 6. Öğrencilerin baba eğitim dereceleri ile toplam sosyal uyum puanlarının tek yönlü varyans analizi (ANOVA) sonuçları

\begin{tabular}{|c|c|c|c|c|c|c|c|c|c|}
\hline $\begin{array}{c}\text { Baba E. } \\
\text { D. }\end{array}$ & N & Ort & Ss & $\begin{array}{c}\text { Varyans } \\
\text { K. }\end{array}$ & K. T. & sd & K. O. & F & p \\
\hline $\begin{array}{c}\text { Okuma- } \\
\text { Yazma } \\
\text { Bil }\end{array}$ & 18 & 136,944 & 37,48015 & G. Aras1 & 6194,225 & 4 & 1548,556 & 0,980 & 0,418 \\
\hline İlkokul & 86 & 157,0349 & 39,75467 & G. İçi & 681320,5 & 431 & 1580,790 & & \\
\hline Ortaokul & 100 & 154,7500 & 42,77198 & Toplam & & 435 & & & \\
\hline Lise & 158 & 153,5823 & 37,28684 & & & & & & \\
\hline $\begin{array}{c}\text { Lisans ve } \\
\text { Üstü }\end{array}$ & 74 & 155,0811 & 41,16614 & & & & & & \\
\hline
\end{tabular}

Araştırmaya katılan öğrencilerin babalarının eğitim düzeylerine göre toplam sosyal uyum puanlarının anlamlı bir farklılık gösterip göstermediğini saptama amacıyla Tek Yönlü Varyans Analizi (ANOVA) yapılmış ve iki grup ortalamaları arasında istatistiksel olarak anlamlı bir fark olmadığı görülmüştür ( $\mathrm{f}=0,980 \mathrm{p}>0,05)$.

Tablo 7. Örencilerin kardeş sayıları ile toplam sosyal uyum puanlarının tek yönlü varyans analizi sonuçları

\begin{tabular}{|c|c|c|c|c|c|c|c|c|c|}
\hline Kardeş S. & N & Ort & Ss & $\begin{array}{c}\text { Varyans } \\
\text { K. }\end{array}$ & K. T. & sd & K. O. & F & p \\
\hline $\begin{array}{c}\text { Tek } \\
\text { Çocuk }\end{array}$ & 49 & 151,622 & 39,46402 & G. Aras1 & 24198,988 & 3 & 8066,329 & 5,252 & 0,001 \\
\hline 1 Kardeş & 210 & 160,8667 & 37,57240 & G. İçi & 658860,6 & 429 & 1535,806 & & \\
\hline 2 Kardes & 111 & 149,5495 & 39,79830 & Toplam & 683059,6 & 432 & & & \\
\hline $\begin{array}{c}3 \text { Kardeş } \\
\text { ve Daha } \\
\text { Fazla }\end{array}$ & 63 & 140,3016 & 43,0361 & & & & & & \\
\hline
\end{tabular}

Araştırmaya katılan öğrencilerin kardeş sayılarına göre toplam sosyal uyum puanlarının anlamlı bir farklılık gösterip göstermediğini saptama amacıyla Tek Yönlü Varyans Analizi (ANOVA) yapılmış ve grup ortalamaları arasında istatistiksel olarak anlamlı bir fark olduğu görülmüş̧ür $(\mathrm{f}=5,252 \mathrm{p}<0,05)$. Bu farklılığın hangi gruplar arasında olduğunu belirlemek için Tukey Testi yapılmış ve 1 kardeşi olan öğrencilerin sosyal uyum düzeylerinin, 3 ve daha fazla kardeşi olan öğrencilerin sosyal uyum düzeylerinden anlamlı bir fark olduğu diğer gruplar arasında anlamlı farklılık olmadığı görülmüştür.

Tablo 8. Öğrencilerin anne babalarının birliktelik durumu ile sosyal uyum toplam puanlarının bağımsız örneklem t testi sonuçları

\begin{tabular}{|c|c|c|c|c|c|}
\hline & $\mathrm{N}$ & Ort & Ss & $\mathrm{t}$ & $\mathrm{p}$ \\
\hline $\begin{array}{c}\text { Anne Baba } \\
\text { Birlikte }\end{array}$ & 396 & 154,9646 & 38,74237 & 1,197 & 0.232 \\
\hline Anne Baba Ayr1 & 39 & 147,0000 & 48,12265 & & \\
\hline
\end{tabular}

Araştırmaya katılan öğrencilerin anne babalarının birliktelik durumlarına göre toplam sosyal uyum puanlarının anlamlı bir farklılık gösterip göstermediğini saptama amacıyla Bağımsız Örneklem T-Testi yapılmış ve iki grup ortalamaları arasında istatistiksel olarak anlamlı bir fark olmadığ görülmüştür $(t=1,197 \mathrm{p}>0,05)$. 

2012-2013 Between 60-66 Months and Over 66 Months

Tablo 9. Öğrencilerin okul öncesi eğitim durumu ile sosyal uyum toplam puanlarının bağımsız örneklem $\mathrm{t}$ testi sonuçları

\begin{tabular}{|c|c|c|c|c|c|}
\hline & $\mathrm{N}$ & Ort & Ss & $\mathrm{t}$ & $\mathrm{p}$ \\
\hline Okul Öncesi Eğitim Almış & 248 & 156,0806 & 40,76040 & 1,196 & 0,23 \\
\hline $\begin{array}{c}\text { Okul Öncesi Eğitim } \\
\text { Almamış }\end{array}$ & 188 & 151,4840 & 38,34037 & & \\
\hline
\end{tabular}

Araştırmaya katılan öğrencilerin okul öncesi eğitim alma durumlarına göre toplam sosyal uyum puanlarının anlamlı bir farklılık gösterip göstermediğini saptama amacıyla Bağımsız Örneklem T-Testi yapılmış ve iki grup ortalamaları arasında istatistiksel olarak anlamlı bir fark olmadığı görülmüştür $(\mathrm{t}=1,196 \mathrm{p}>0,05)$.

Tablo 10. Öğrencilerin ilkokulda öğretmen değişikliği yaşama durumu ile sosyal uyum toplam puanlarının bağımsız örneklem t testi sonuçları

\begin{tabular}{|c|c|c|c|c|l|}
\hline & $\mathrm{N}$ & Ort & Ss & $\mathrm{t}$ & $\mathrm{p}$ \\
\hline İlkokula Öğretmen Değiştirmiş & 82 & 154,8736 & 40,28792 & 0,344 & 0,731 \\
\hline $\begin{array}{c}\text { İlkokulda Öğretmen } \\
\text { Değiştirmemiş }\end{array}$ & 54 & 153,5433 & 39,43990 & & \\
\hline
\end{tabular}

Araştırmaya katılan öğrencilerin ilkokulda öğretmen değişikliği yaşayıp yaşamama durumlarına göre toplam sosyal uyum puanlarının anlamlı bir farklılık gösterip göstermediğini saptama amacıyla Bağımsız Örneklem T-Testi yapılmış ve iki grup ortalamaları arasında istatistiksel olarak anlamlı bir fark olmadığı görülmüştür $(\mathrm{t}=0,344$ p > 0,05). Benlik saygısı ile sosyo-demografik değişkenler (Cinsiyet, anne- baba eğitim derecesi, kardeş sayıs1, anne baba birliktelik durumu, okul öncesi eğitim durumu ve ilkokulda öğretmen değişikliği yaşayıp yaşamama durumu) arasındaki ilişkiye bakılırken Bağımsız Örneklem T Testi ve Tek Yönlü Varyans Analizi yapılmış ve analiz sonuçları Tablo-11, Tablo-12, Tablo-13, Tablo-14, Tablo-15, Tablo-16 ve Tablo-17'de verilmiştir.

Tablo 11. Öğrencilerin cinsiyetleri ile benlik saygısı toplam puanlarının bağımsız örneklem t-testi sonuçları

\begin{tabular}{|c|c|c|c|c|c|}
\hline & $\mathrm{N}$ & Ort & Ss & \multicolumn{1}{|c|}{$\mathrm{t}$} & $\mathrm{p}$ \\
\hline $\mathrm{K} 1 \mathrm{z}$ & 218 & 72.9908 & 18.28121 & 0,975 & 0,330 \\
\hline Erkek & 217 & 71.3871 & 15.92103 & & \\
\hline
\end{tabular}

Araştırmaya katılan öğrencilerin cinsiyetlerine göre toplam benlik saygısı puanlarının anlamlı bir farklılık gösterip göstermediğini saptama amacıyla Bağımsız Örneklem T-Testi yapılmış ve iki grup ortalamaları arasında istatistiksel olarak anlamlı bir fark olmadığ görülmüştür ( $\mathrm{t}=0,975 \mathrm{p}>0,05)$.

Tablo 12. Öğrencilerin anne eğitim dereceleri ile benlik saygısı toplam puanlarının tek yönlü varyans analizi sonuçları

\begin{tabular}{|c|c|c|c|c|c|c|c|c|c|}
\hline $\begin{array}{c}\text { Anne E. } \\
\text { D. }\end{array}$ & N & Ort & Ss & $\begin{array}{c}\text { Varyans } \\
\text { K. }\end{array}$ & K. T. & sd & K. O. & F & p \\
\hline $\begin{array}{c}\text { Okuma- } \\
\text { Yazma Bil }\end{array}$ & 20 & 67,000 & 17,78823 & G. Aras1 & 3641,813 & 4 & 910,453 & 3,166 & 0,014 \\
\hline İlkokul & 134 & 69,9925 & 19,14664 & G. İçi & 123928,9 & 431 & 287,538 & & \\
\hline Ortaokul & 104 & 70,2692 & 16,08487 & Toplam & 127570,7 & 435 & & & \\
\hline Lise & 122 & 75,0492 & 16,00044 & & & & & & \\
\hline $\begin{array}{c}\text { Lisans ve } \\
\text { Üstü }\end{array}$ & 56 & 76,5714 & 14,4816 & & & & & & \\
\hline
\end{tabular}

Araştırmaya katılan öğrencilerin annelerinin eğitim derecelerine göre toplam benlik saygısı puanlarının anlamlı bir farklılık gösterip göstermediğini saptama amacıyla Tek Yönlü Varyans Analizi (ANOVA) yapılmış ve iki grup ortalamaları arasında istatistiksel olarak 
anlamlı bir fark olduğu görülmüştür $(\mathrm{f}=3,166 \mathrm{p}<0,05)$. Bu farklıllı̆̆ı hangi gruplar arasında olduğunu belirlemek için Tukey Testi yapılmış ve anne eğitim derecesine göre benlik saygısı puanları arasında anlamlı bir farklılık olmadığı saptanmıştır.

Tablo 13. Öğrencilerin baba eğitim dereceleri ile benlik saygısı toplam puanlarının tek yönlü varyans analizi sonuçları

\begin{tabular}{|c|c|c|c|c|c|c|c|c|c|}
\hline $\begin{array}{c}\text { Baba E. } \\
\text { D. }\end{array}$ & N & Ort & Ss & $\begin{array}{c}\text { Varyans } \\
\text { K. }\end{array}$ & K. T. & sd & K. O. & F & p \\
\hline $\begin{array}{c}\text { Okuma- } \\
\text { Yazma Bil }\end{array}$ & 18 & 69,778 & 19,98692 & G. Aras1 & 3996,144 & 4 & 999,036 & 3,484 & 0,008 \\
\hline İlkokul & 86 & 67,8488 & 19,78919 & G. İçi & 123574,5 & 431 & 286,716 & & \\
\hline Ortaokul & 100 & 69,9600 & 16,30512 & Toplam & 127570,7 & 435 & & & \\
\hline Lise & 158 & 74,6835 & 16,33062 & & & & & & \\
\hline $\begin{array}{c}\text { Lisans ve } \\
\text { Üstü }\end{array}$ & 74 & 75,4595 & 17,12501 & & & & & & \\
\hline
\end{tabular}

Araştırmaya katılan öğrencilerin babalarının eğitim derecelerine göre toplam benlik saygısı puanlarının anlamlı bir farklılık gösterip göstermediğini saptama amacıyla Tek Yönlü Varyans Analizi (ANOVA) yapılmış ve iki grup ortalamaları arasında istatistiksel olarak anlamlı bir fark olduğu görülmüştür $(\mathrm{f}=3,484 \mathrm{p}<0,05)$. Bu farklılığın hangi gruplar arasında olduğunu belirlemek için Tukey Testi yapılmış ve babası lise mezunu olanların benlik saygıları ile babası ilkokul mezunu olanların enlik saygıları arasında anlamlı bir farklılık olduğu saptanmıştır.

Tablo 14. Öğrencilerin kardeș sayıları ile benlik saygısı toplam puanlarının tek yönlü varyans analizi sonuçları

\begin{tabular}{|c|c|c|c|c|c|c|c|c|c|}
\hline $\begin{array}{c}\text { Kardeş } \\
\text { Sayıs1 }\end{array}$ & N & Ort & Ss & $\begin{array}{c}\text { Varyans } \\
\text { K. }\end{array}$ & K. T. & sd & K. O. & F & p \\
\hline $\begin{array}{c}\text { Tek } \\
\text { Çocuk }\end{array}$ & 49 & 72,5714 & 18,51126 & G. Aras1 & 3408,616 & 3 & 1136,205 & 3,931 & 0,009 \\
\hline 1 Kardeş & 210 & 74,7238 & 15,54281 & G. İçi & 124007,2 & 429 & 289,061 & & \\
\hline 2 Kardeş & 111 & 69,697 & 15,94125 & Toplam & 127415,8 & 432 & & & \\
\hline $\begin{array}{c}\text { 3 Kardeş } \\
\text { ve Daha } \\
\text { Fazlas1 }\end{array}$ & 63 & 67,5397 & 21,67042 & & & & & & \\
\hline
\end{tabular}

Araştırmaya katılan öğrencilerin kardeş sayılarına göre toplam benlik saygısı puanlarının anlamlı bir farklılık gösterip göstermediğini saptama amacıyla Tek Yönlü Varyans Analizi (ANOVA) yapılmış ve iki grup ortalamaları arasında istatistiksel olarak anlamlı bir fark olduğu görülmüștür $(\mathrm{f}=3,931 \mathrm{p}<0,05)$. Bu farkl1lığın hangi gruplar arasında olduğunu belirlemek için Tukey Testi yapılmış ve 1 kardeşi olan öğrencilerin benlik saygılarının 3 ve daha fazla kardeşi olanların benlik saygılarından anlamlı farklılık gösterdiği saptanmiştır.

Tablo 15. Öğrencilerin anne babalarının birliktelik durumları ile benlik saygısı toplam puanlarının bağımsız örneklem $t$ testi sonuçları

\begin{tabular}{|l|c|c|c|c|c|}
\hline & $\mathrm{N}$ & Ort & Ss & $\mathrm{t}$ & $\mathrm{p}$ \\
\hline Anne Baba Birlikte & 396 & 72,7551 & 17,28622 & 2,161 & 0,031 \\
\hline Anne Baba Ayr1 & 39 & 66,5641 & 14,61037 & & \\
\hline
\end{tabular}

Araştırmaya katılan öğrencilerin anne babalarının birliktelik durumuna göre toplam benlik saygısı puanlarının anlamlı bir farklılık gösterip göstermediğini saptama amacıyla Bağımsız Örneklem T Testi yapılmış ve iki grup ortalamaları arasında istatistiksel olarak anlamlı bir fark olduğu görülmüştür $(\mathrm{t}=2,161 \mathrm{p}<0,05)$. İki grubun ortalamalarına bakıldığında, anne babaları birlikte olanların benlik saygısı puan ortalamalarının anne babası ayrı olanlardan daha yüksek olduğu görülmektedir. 

2012-2013 Between 60-66 Months and Over 66 Months

Tablo 16. Öğrencilerin okul öncesi eğitim durumları ile benlik saygısı toplam puanlarının bağımsız örneklem t testi sonuçları

\begin{tabular}{|c|c|c|c|c|c|}
\hline & $\mathrm{N}$ & Ort & \multicolumn{1}{|c|}{ Ss } & $\mathrm{t}$ & $\mathrm{p}$ \\
\hline Okul Öncesi Ĕ̆itim Almış & 248 & 72,5282 & 17,22203 & 0,486 & 0,628 \\
\hline $\begin{array}{c}\text { Okul Öncesi Ĕ̆itim } \\
\text { Almamış }\end{array}$ & 188 & 71,7234 & 17,03121 & & \\
\hline
\end{tabular}

Araştırmaya katılan öğrencilerin okul öncesi eğitim alıp almadıklarına göre toplam benlik saygısı puanlarının anlamlı bir farklılık gösterip göstermediğini saptama amacıyla Bağımsız Örneklem T Testi yapılmış ve iki grup ortalamaları arasında istatistiksel olarak anlamlı bir fark olmadığı görülmüştür $(t=0,486 \mathrm{p}>0,05)$.

Tablo 17. Öğrencilerin ilkokulda öğretmen değişikliği yaşama durumları ile benlik saygısı toplam puanlarının bağımsız örneklem $\mathrm{t}$ testi sonuçları

\begin{tabular}{|l|c|c|c|c|c|}
\hline & $\mathrm{N}$ & Ort & Ss & t & p \\
\hline İlkokulda Öğretmen Değişikliğgi Yaşamış & 205 & 72,8791 & 16,79571 & 0,720 & 0,35 \\
\hline İlkokulda Öğretmen Değişikliği Yaşamamış & 287 & 71,6811 & 17,3728 & & \\
\hline
\end{tabular}

Araştırmaya katılan öğrencilerin ilkokulda öğretmen değişikliği yaşayıp yaşamama durumuna göre toplam benlik saygısı puanlarının anlamlı bir farklılık gösterip göstermediğini saptama amacıyla Bağımsız Örneklem $\mathrm{T}$ Testi yapılmış ve iki grup ortalamaları arasında istatistiksel olarak anlamlı bir fark olmadığı görülmüştür $(t=0,720$ $\mathrm{p}>0,05)$.

\section{Tartışma, Sonuç ve Öneriler}

Araştırma bulgularına göre, 60-66 ay arasında ve 67 ay ve üzerinde başlamış olan beşinci sınıf öğrencilerinin okula başlama yaşları ile sosyal uyum toplam puanları arasında istatistiksel olarak anlamlı bir fark olmadığı sonucuna ulaşılmıştır. Alanyazın incelendiğinde yaşın sosyal uyum düzeyi üzerindeki etkisini inceleyen sınırlı sayıda araştırma olduğu görülmüştür. Yapılan araştırmalarda ise okula başlama yaşının birinci sınıfta sosyal problem çözme becerileri ve sosyal uyum düzeylerini etkilediği yönünde sonuçlar olduğu görülmektedir (Y1lmaz \& Tepeli, 2013; Dirlik, 2014; Merter, Şekerci \& Bozkurt, 2014). Mevcut araştırma bulguları incelendiğinde 5. sınıfta öğrencilerin 1. Sınıfa başlama yaşlarının sosyal uyum düzeyleri üzerinde istatistiksel olarak anlamlı bir fark olmadığı görülmektedir. Bu sonuçlara göre, ilkokula başlama yaşının 1. Sınıftaki sosyal uyum düzeyi üzerindeki etkilerinin 5. sinıfta devam etmediği söylenebilir.

60-66 ay arasında ve 67 ay ve üzerinde başlamış olan beşinci sınıf öğrencilerinin okula başlama yaşları ile benlik saygısı toplam puanları arasında istatistiksel olarak anlamlı bir fark olmadığı sonucuna ulaşılmıştır. Ünlü (2015) yaptığı araştırmada mevcut araştırma ile benzer sonuçlara ulaşmış ve yaş ile benlik saygısı arasında anlamlı bir farklılık olmadığını belirtmiştir. Bunun yanı sıra Yılmaz ve Ekinci'nin (2001) yaptığı araştırmada da yaş ile benlik saygısı arasında ilişki olmadığı sonucuna ulaşılmıştır. Altıok, Ek ve Koruklu (2010), üniversite öğrencilerinin benlik saygıları ile bazı değişkenleri incelediği araştırmada yaşları 20-25 arasında olanların 17-19 arasında olanlardan anlamlı bir düzeyde yüksek olduğu sonucuna ulaşmışlardır.

Benlik saygısı ile sosyal uyum arasındaki ilişkiye dair korelasyon analizi sonuçlarına göre benlik saygısı ile; öğretmen tercihli sosyal davranış arasında pozitif ( $\mathrm{r}=0,232$, $\mathrm{p}<0,05)$, akran tercihli sosyal davranış arasında pozitif $(\mathrm{r}=0,268, \mathrm{p}<0,05)$, okula uyum 
arasında pozitif ( $\mathrm{r}=0,270, \mathrm{p}<0,005$ ) ve sosyal uyum düzeyi ile pozitif yönlü ilişki olduğu görülmüştür $(\mathrm{r}=0,267, \mathrm{p}<0,05)$. Sungur'a (2016) göre iki değişken arasındaki ilişkiye bakı1ırken $r=0,00$ ile 0,25 arasında ise ilişki çok zayıftır, 0,26 ile 0,49 arasında ise ilişki zayıftır, 0,50 ile 0,69 arasında ise ilişki orta düzeydedir. 0,70 ile 0,89 arasında ise ilişki yüksek düzeydedir ve 0,90 ile 1,00 arasında ise çok yüksek düzeydedir. Buna göre araştırma bulgularına göre sosyal uyum ile benlik saygısı arasında pozitif yönlü düşük düzeyde ilişki vardır. Bu durumda sosyal uyum düzeyi arttıkça benlik saygısı da artabileceği söylenebilir. Ayvalı (2012) da benzer bir şekilde, 4 ve 5. sınıflarla yaptığı araştırmada benlik saygısı yükseldikçe sosyal uyum düzeyinin de yükseldiği sonucuna ulaşmıştır.

Öğrencilerin cinsiyetlerine göre sosyal uyum düzeylerinde anlamlı bir fark olup olmadığına dair yapılan Bağımsız Örneklem T Testi sonuçlarına göre öğrencilerin toplam sosyal uyum puanları ile cinsiyet arasında istatistiksel olarak anlamlı farklılaşma olduğu görülmüştür. Öğrencilerin cinsiyetlerine göre sosyal uyum puanlarının ortalamaları incelendiğinde kızların ortalamalarının erkeklerinkinden daha yüksek olduğu görülmüsstür. Cinsiyetin sosyal uyum düzeyi üzerindeki etkilerine ilişkin yapılan araştırma sonuçlarının bir kısmı, cinsiyet ile sosyal uyum düzeyi arasında anlamlı bir fark olmadığı (Karayılmaz, 2008; Yeğen, 2008; Sungur, 2010; Aras, 2015), bir kısmı ise anlamlı fark olduğu ve bu farkın da kızların lehine olduğu yönündedir (Aysan \& Uz Baş, 2004; Çelik, 2007; Güngören 2011; Kandır \& Orçay, 2011; Dirlik, 2014; Erdemir, 2015). Bu durumda cinsiyetin sosyal uyuma etkilerine ilişkin araştırma sonuçlarının tutarlı olmadığı söylenebilir.

Öğrencilerin kardeş sayılarına göre sosyal uyum düzeylerinde anlamlı farklılaşma olup olmadığına dair yapılan Tek Yönlü Varyans Analizi (ANOVA) sonuçlarına göre öğrencilerin kardeş sayılarına göre sosyal uyum düzeyleri anlamlı bir şekilde farklılaşmaktadır. Öğrencilerin kardeş sayılarına göre toplam sosyal uyum puan ortalamaları incelendiğinde, 1 kardeşi olanların toplam sosyal uyum puan ortalamalarının tek çocuk olanların ortalamalarından ve 2 ve daha fazla kardeşi olanların ortalamalarının anlamlı bir şekilde yüksek olduğu görülmüştür. Mevcut araştırma sonuçları ile paralel olarak Aysan ve Uz Baş (2004), kardeş sayısına göre sosyal uyum düzeyinin değiştiği sonucuna ulaşmışlardır. Alanyazındaki bazı araştırma sonuçları mevcut araştırmanın tersine kardeş sayısının sosyal uyumu etkilemediği yönündedir (Erdemir, 2015; Güngören, 2011; Karayılmaz, 2008; Sungur, 2010).

Öğrencilerin anne babalarının birliktelik durumlarına göre sosyal uyum düzeylerinde anlamlı bir fark olup olmadığına dair yapılan Bağımsız Örneklem T Testi sonuçlarına göre öğrencilerin toplam sosyal uyum puanları ile anne ve babalarının birliktelik durumları arasında istatistiksel olarak anlamlı bir fark olmadığı görülmüş̧ür. Aysan ve Uz Baş'ın (2004) ilkokul 4 ve beşinci sınıf öğrencileri ile yaptıkları araştırmada anne babası birlikte olanların sosyal uyum düzeylerinin boşanmış olanlardan daha yüksek olduğu sonucuna ulaşmışlardır. Mevcut araştırmanın sonucunda anne baba birliktelik durumu ile sosyal uyum arasında anlamlı farklılık bulunamamıştır. Bu durumda araştırma bulgularının Aysan ve Uz Baş'ın (2004) yaptıkları araştırmanın sonucuyla tutarlı olmadığı söylenebilir.

Öğrencilerin anne- baba eğitim düzeylerine göre sosyal uyum düzeyinde anlaml1 farklılaşma olup olmadığına bakmak için yapılan Tek Yönlü Varyans Analizi (ANOVA) sonuçlarına göre öğrencilerin toplam sosyal uyum puanları ile anne ve babalarının eğitim düzeyleri arasında istatistiksel olarak anlamlı bir fark olmadığı görülmüştür. Aynı zamanda 

2012-2013 Between 60-66 Months and Over 66 Months

anne baba eğitim düzeyi ile sosyal uyum arasında anlamlı bir farklılaşma olmadığı görülmüştür. Alanyazında yer alan araştırma sonuçlarına göre anne ve baba eğitim düzeyinin sosyal uyum üzerinde etkili olduğu, anne baba eğitim düzeyleri yükseldikçe sosyal uyum düzeyinin de arttığı ve bu sonuçların mevcut araştırma bulguları ile tutarlı olmadığ görülmüştür (Yeğen, 2008; Sungur, 2010; Güngören, 2011; Uğurlu, 2012.).

Öğrencilerin okul öncesi eğitim alma durumları ile sosyal uyum düzeyleri arasında anlamlı bir fark olup olmadığına bakılması için Bağımsız Örneklem T Testi yapılmış ve öğrencilerin okula uyum puanları ile okul öncesi kuruma devam etme durumu arasında anlamlı fark olduğu görülmüştür. Buna göre okul öncesi eğitim almış olan öğrencilerin ortalamalarının almamış olanlardan anlamlı bir şekilde yüksek olduğu görülmüş̧ür.

Öğrencilerin cinsiyetlerine göre benlik saygısı düzeylerinde farklılaşma olup olmadığına dair yapılan Bağımsız Örneklem $\mathrm{T}$ Testi sonuçlarına göre öğrencilerin cinsiyetleri ile toplam benlik saygısı puanları arasında istatistiksel olarak anlamlı bir fark olmadığı görülmüştür. Alanyazında cinsiyetin benlik saygısı üzerindeki etkili olup olmadığ 1 konusundaki sonuçlarda tutarsızlık olduğu görülmüsstür. Araştırmaların bir bölümündeki sonuçlar cinsiyet ile benlik saygısı arasında anlamlı bir farklılık olmadığını göstermektedir (Yelsma \& Yelsma, 1998; İkiz \& Çakar, 2006; Dilek, 2007; Lian, 2008; Seçer, Ay, İlbay \& Çiftçi. 2012; Ceylan, 2013; Ünlü, 2015). Cinsiyet ile benlik saygısı arasında anlamlı farklılık olduğu sonucuna ulaşan araştırmalarda ise büyük bir kısmı kızların benlik saygısının erkeklerin benlik saygısından daha yüksek olduğunu belirtmektedir. (Hamarata, 2004; Altıok, Ek \& Koruklu, 2010; Karataş, 2012; Türedi, 2015). Bunun yanında Sarıkaya'nın (2015) yaptığı araştırmanın sonucunda erkeklerin benlik saygısının kızların benlik saygısından daha yüksek olduğu görülmüştür.

Öğrencilerin kardeş sayılarına göre benlik saygısı düzeylerinde anlamlı bir farklılaşma olup olmadığına bakılması için Tek Yönlü Varyans Analizi (ANOVA) yapılmış ve öğrencilerin kardeş sayıları ile toplam benlik saygısı puanları arasında istatistiksel olarak anlamlı farklılaşma olduğu görülmüş̧ür. Kardeşi olmayan ve 1 kardeşi olan öğrencilerin benlik saygılarının 2 ve daha fazla kardeşi olanlardan anlamlı bir şekilde yüksek olduğu görülmüştür. Alanyazında kardeş sayısının benlik saygısı üzerindeki etkilerine dair yapılan araştırmalarda mevcut araştırmanın tersine kardeş sayısının benlik saygısı üzerinde anlamlı farklılık oluşturmadığı belirtilmektedir (Yılmaz, \& Ekinci, 2001; Erbil, Divan \& Önder, 2006; Dilek, 2007; Ceylan, 2013; Yücel, 2013; Çetin, 2015).

Öğrencilerin anne babalarının birliktelik durumlarına göre benlik saygıs1 düzeylerinde anlamlı farklılaşma olup olmadığına bakılması için Bağımsız Örneklem T Testi Yapılmış ve öğrencilerin anne babalarının birliktelik durumları ile toplam benlik saygısı puanları arasında istatistiksel olarak anlamlı bir fark olduğu görülmüştür. Buna göre anne babaları birlikte olan öğrencilerin benlik saygılarının, ayrı olanlardan anlamlı bir şekilde daha yüksek olduğu görülmüştür. Mevcut araştırma sonucuna göre çocuğun ebeveynleri ile birlikte büyümesi çocuğun benlik saygısını etkilediği söylenebilir. Alanyazın incelendiğinde, Sarıkaya (2015) ve Çetin (2015) yaptıkları araştırmalarda mevcut araştırma ile benzer sonuçlar elde ederek anne babaları birlikte yaşayanların benlik saygısının anne babaları ayrı yaşayanlardan anlamlı bir şekilde yüksek olduğu sonucuna ulaşmışlardır. 
Öğrencilerin anne-baba eğitim durumlarına göre benlik saygısı düzeylerinde anlamlı farklılaşma olup olmadığına bakılması için Tek Yönlü Varyans Analizi (ANOVA) yapılmış ve öğrencilerin anne babalarının eğitim düzeyleri ile toplam benlik saygısı puanları arasında istatistiksel olarak anlamlı bir fark olduğu ve anne- baba eğitim düzeyleri yükseldikçe öğrencilerin benlik saygıları düzeylerinin de yükseldiği görülmüş̧ür. Anne-baba eğitim durumunun benlik saygısına etkilerini inceleyen araştırma sonuçlarının bir kısmında anne ve baba eğitim düzeyi arttıkça benlik saygısının da arttı̆̆1 (Ayvalı, 2012; Çetin, 2015) bir kısmında anne eğitim düzeyi arttıkça benlik saygısının arttığı (Erbil, Divan \& Önder, 2006) bir kısmında baba eğitim düzeyi yükseldikçe benlik saygısının arttı̆̆ (Bal, 2005) bir kısmında ise anne- baba eğitim düzeyi ile benlik saygısı arasında anlamlı bir farklılaşma olmadığı (Dilek, 2007; Ceylan, 2013; Sarıkaya, 2015) yönündedir.

Sonuç olarak sosyal uyum ile benlik saygısı arasında anlamlı ilişki olduğu, öğrencilerin cinsiyetlerinin sosyal uyum düzeylerinde farklılaşmaya sebep olduğunu ve kız öğrencilerin sosyal uyum düzeylerinin erkeklerinkinden daha yüksek olduğu görülmüştür. Kardeş sayısının da sosyal uyum düzeyinde farklılaşmaya sebep olduğu görülmüştür. Bir kardeşi olanların sosyal uyum düzeylerinin tek çocuk olanlardan ve 2 ve daha fazla kardeşi olanlardan daha yüksek olduğu görülmüştür. Okul öncesi eğitim almış olan öğrencilerin okula uyum puanlarının okul öncesi eğitim almamış olanlardan daha yüksek olduğu görülmüştür.

Anne babası birlikte olan öğrencilerin benlik saygılarının ayrı olanlardan daha yüksek olduğu, tek çocuk olanların ve 1 kardeşi olanların 2 ve daha fazla kardeşi olanlardan benlik saygısı düzeylerinin anlamlı bir şekilde yüksek olduğu ve anne- baba eğitim düzeyi yükseldikçe öğrencilerin benlik saygısı düzeylerinin yükseldiği görülmüştür.

Birinci Sınıfta okula başlama yaşının beşinci sınıfta benlik saygısı ve sosyal uyum düzeyi ile ilişkili olmadığı görülmüştür. Alanyazında birinci sınıf öğrencileri ile yapılan çalışmalarda okula erken başlamanın olumsuz etkileri olduğu vurgulanmaktadır. $\mathrm{Bu}$ araştırmalara göre, okula erken başlayan çocukların geç başlayanlara göre okula hazırbulunuşluk düzeyleri daha düşük olduğundan (Kahramanoğlu, Tiryaki \& Canpolat, 2014; Merter, Şekerci \& Bozkurt, 2014) ve okul olgunlukları geç başlayanlara göre daha geç oluştuğundan (Gündüz \& Çalışkan, 2013 \& Bayat, 2015) birinci sınıfta akademik başarısızlık yaşamakta (Crosser, 1991; Kawaguchi, 2011; Tutal, 2013; Durna, 2014; Kartal, Bilgin \& Bolattekin, 2016), sosyal uyum düzeyleri düşmekte (Dirlik, 2014) ve okul korkusu veya psikosomatik sorunlar yaşamaktadırlar (Yavuzer, 2004) Mevcut araştırma sonuçlarına göre alanyazındaki araştırma sonuçlarında yer alan okula erken başlamanın olumsuz etkilerinin, beşinci sınıfta öğrencilerin benlik saygıları ve sosyal uyum düzeylerinde okula erken başlayanların geç başlayanlar arasında bir farklılaşmaya sebep olmadığı söylenebilir.

Araştırma İstanbul'un Kartal ilçesinde beşinci sınıf öğrencilerine uygulanmıştır. Farklı örneklem grubu üzerinde aynı araştırma yapılmasının araştırmanın genellenebilirliği açısından yararlı olacağı düşünülmektedir. Aynı zamanda bu araştırma ilkokul öğrencilerine de yapılabilir. Böylece okula başlama yaşının erken dönem etkileri konusunda daha çok fikir sahibi olunabilir.

Araştırmada kullanılan Walker- McCannel Sosyal Yeterlik ve Okula Uyum Ölçeği öğretmen gözlemi ile doldurulmaktadır. $\mathrm{Bu}$ da araştırma verilerin sadece öğretmen 

2012-2013 Between 60-66 Months and Over 66 Months

gözlemine dayanmasına ve verilerin subjektif olmasına sebep olabilir. Bu nedenle yapılacak araştırmanın daha objektif olması adına sosyal uyum düzeyi belirlenirken öğretmen aile ve bireyin kendisinden veri toplamaya yönelik ölçme aracı geliştirilebilir.

Araştırmanın ana amacı okula başlama yaşının sosyal uyum düzeyi ve benlik saygısına etkilerinin araştırılması idi. Okula başlama yaşının etkileri birinci sınıftan başlanıp ortaöğretim sonuna kadar boylamsal olarak takip edildiğinde ana problem ile ilgili daha sağlıklı veri elde edileceği düşünülmektedir. Bu sebeple gelecek araştırmalarda aynı araştırmanın boylamsal olarak yapılası önerilmektedir.

Erkek öğrencilerin sosyal uyum düzeylerini arttırmak için erken çocukluk dönemi itibari ile aile eğitimi ile okula başladıktan sonra okul rehber öğretmenlerince sosyal uyum becerileri eğitimleri verilmesi önerilmektedir.

Kardeş sayısının benlik saygısı ve sosyal uyum düzeyi üzerindeki etkileri göz önüne alındığında tek çocuk olanlar ile 2 ve daha fazla kardeşi olanların sosyal uyum düzeylerinin 1 kardeşi olanlardan düşük olması çok çocuklu ailelerde ebeveynlerin çocukları ile bireysel olarak ilgilenme zamanlarının azalması ve dolayısı ile ebeveynleri tarafindan sosyal becerilerinin yeteri kadar gözlemlenemediği için önlem alınamaması sebebi ile ve tek çocuklu ailelerde çocukların akranları ile iletişim kurma imkanlarının az olmasından kaynaklı olabileceği düşünülmektedir. Bu sebeple Aile Danışmanlığı Merkezlerince ya da okul rehberlik servislerince ailelere çocukların sosyal becerilerini arttırmak için yapılabilecekler konusunda eğitim verilmesi önerilmektedir. Çocukların sosyal becerilerini geliştirebilmeleri ve erken yaşta sosyal uyum düzeylerini arttırabilmeleri için her sosyoekonomik seviyeden ailelerin çocuklarını gönderebilecekleri erken çocukluk eğitimi veren eğitim kurumlarının yaygınlaştırılması önerilmektedir.

Araştırma sonucunda anne- baba eğitim düzeyi arttıkça çocukların benlik saygısı düzeylerinin de artması çocuğun dünyasında anne-babanın yerinin ne kadar önemli olduğunu ortaya koymaktadır. Hem anne hem de babalar için çocuk gelişimi ve bilinçli çocuk yetiştirme konusunda anne-baba eğitim programlarının yaygınlaştırılması ve mevcut annebaba eğitim programlara katılımın yaygınlaştırılması için kamuda ve belediyelerde çalışmalar yapılması önerilmektedir.

Araştırma sonucunda okul öncesi eğitim almış olan öğrencilerin benlik saygıs1 düzeylerinin okul öncesi eğitim almamış olan öğrencilerin benlik saygısı düzeyinden anlamlı şekilde yüksek çıkmış olması erken çocukluk eğitiminin önemini bir kez daha ortaya koyduğu düşünülmektedir. Bu sebeple tüm çocukların erken çocukluk eğitimi alabilmeleri için okul öncesi eğitimin zorunlu olması önerilmektedir.

Araştırmanın bir diğer sonucuna göre ise anne-babası birlikte yaşayan öğrencilerin benlik saygısı düzeylerinin ayrı olanlardan daha yüksek olduğu görülmüştür. Türkiye İstatistik Kurumu'nun (2017) verilerine göre evlilik sürelerine göre boşanma oranları incelendiğinde 2015 ve 2016 yılında evlilik süresi 1- 5 yıl arasında olanların, evlilik süreleri 1 yıldan az ve 6 yıldan fazla olanlara göre boşanma oranları daha yüksek olduğu görülmüştür. Evlilik süresi 1- 5 yıl arasındayken çocuk sahibi olan ebeveynlerin evlilik sürecindeki olumsuz koşullardan çocuğun da etkileneceği düşünülmektedir. Bu sebeple Aile ve Sosyal Politikalar Bakanlığınca geniş çapta önlemler alınarak, her sosyo-ekonomik seviyeden bireylerin yararlanabileceği evlilik okullarının yaygınlaştırılması önerilmektedir. 


\section{Kaynaklar}

Altık, H. Ö., Ek, N. \& Koruklu, N. (2010). Üniversite Öğrencilerinin Benlik Sayg1 Düzeyi ile İlişkili Bazı Değişkenlerin İncelenmesi. Adnan Menderes Üniversitesi Eğitim Fakültesi Eğitim Bilimleri Dergisi, 1(1), 99- 120.

Angrist, J. D.,\& Krueger, A. B. (1992). The Effect of Age at School Entry on Educational Attainment: An Application of Instrumental Variables With Moments From Two Samples. Journal of the American Statistical Association, 328- 336.

Aras, E. (2015). Üniversite Öğrencilerinin Kişisel ve Sosyal Uyum Düzeylerinin Çeşitli Değişkenlere Göre İncelenmesi. Yüksek Lisans Tezi, Atatürk Üniversitesi, Erzurum.

Aysan, F.,\& Uz Baş, A. (2004). İlköğretim 4. ve 5. Sinıflarda Okuyan Öğrencilerin Sosyal Becerileri ve Okul Uyumu İle Depresyon Düzeyleri Arasındaki İlişkinin İncelenmesi. Abant İzet Baysal Üniversitesi Ë̆itim Fakültesi Dergisi, 4(8), 91-107.

Ayvalı, M. (2012). İlkögretim 4. ve 5. Sinıf Öğrencilerinin Benlik Saygısı İle Sosyal Uyum Düzeyi Illişkisi. Yüksek Lisans Tezi, Ondokuz Mayıs Üniversitesi, Samsun.

Baumeister, R. F., Campbell, J. D., Krueger, J. I., \& Vohs, K. D. (2003). Doeshigh SelfEsteem Cause Better Performance, İnterpersonalsuccess, Happiness, or Healthierli Festyles?.Psychological Science in the Publicinterest, 4(1), 1-44.

Bal, E.Y. (2005). Spor Yapmanin Ergenlerin Benlik Sayglsl ve Öz Yeterliliklerine Etkisi. Yüksek Lisans Tezi, Mersin Üniversitesi, Mersin.

Bayat, S. (2015). İlkokuma Yazma Öğretiminde 60-66 Aylık Çocuklar İle İlgili Yaşanan Güçlüklere İlişkin Öğretmen Görüşleri. Uluslararası Türk Eğitim Bilimleri Dergisi, 3(5), 172- 185.

Berk, L. E. (2013). Çocuk Gelişimi (1. Baskı). (A . Dönmez, Çev.). Ankara: İmge Yayınları

Black, S. E., Devereux, P. J., \& Salvanes, K. G. (2011). TooYoung to Leave the Nest? The Effects of School Starting Age. The Review of Economics and Statistics, 455- 467.

Cameron, M. B. \& Wilson, B. J. (1990). The Effects of Chronological Age, Genderand Delay of Entry on Academic Achievement and Retention: Implications For Academic Redshirtıng. Psychologv in the Schools, 27, 260-263.

Cascio, E. U. \& Schanzenbach, D. W. (2016). First in the Class? Age and the Education Production Function. Education Finance and Policy, 225- 250.

Ceylan, İ. (2013). Ergenlerin Benlik Saygısı ve Duygusal Öz-Yeterlik Düzeylerinin Incelenmesi. Yüksek Lisans Tezi, Dokuz Eylül Üniversitesi, İzmir.

Crosser, S. L. (1991). Summer Birth Date Children: Kindergarten Entrance Age and Academic Achievement. The Journal of Educational Research, 84 (3), 40- 146.

Çelik, N. (2007). Sosyal Beceri Eğitiminin İlköğretim Öğrencilerinin Sosyal Uyum Düzeylerine Etkisi. Yüksek Lisans Tezi. Dokuz Eylül Üniversitesi, İzmir.

Çetin, B. (2015). Kentte ve Kırsalda Yetişmiş Ortaokul Öğrencilerinin Benlik Saygısı ile Saldırganlık Düzeylerinin İncelenmesi. Yüksek Lisans Tezi, Nişantaşı Üniversitesi, İstanbul.

Datar, A. (2006). Does Delaying Kindergarten Entrance Give Children a Head Start?. Economics of Education Review, 25, 63-42.

Dilek, H. (2007). Farklı Eğitim Programlarına Devam Eden Lise 1. Sinıf Öğrencilerinin Benlik Saygısı ile Anne Babalarının Benlik Saygısı Arasındaki İlişkinin İncelenmesi. Yüksek Lisans Tezi, Gazi Üniversitesi, Ankara.

Dirlik, C. (2014). 4+4+4 Ĕgitim Sisteminde 60-66 Aylık Öğrencilerin Okula Hazırbulunuşlukta Sosyal Uyum Düzeylerinin İncelenmesi. Yüksek Lisans Tezi, İstnbul Aydın Üniversitesi- Yıldız Teknik Üniversitesi, İstanbul. 

2012-2013 Between 60-66 Months and Over 66 Months

Durna, Y. (2014). Aynı Sınıfta Öğrenim Gören Altmış Altı ve Yetmiş İki Aylık Öğrencilerin Yaşadı̆̆ı Sorunların Öğretmen Görüşlerine Göre Değerlendirilmesi. Yüksek Lisans Tezi, Atatürk Üniversitesi, Erzincan.

Erbil, N., Divan, Z. \& Önder, P. (2006). Ergenlerin Benlik Saygısına Ailelerinin Tutum ve Davranışlarının Etkisi. Sosyal Politika Çalışmaları Dergisi, 10(10), 7- 15.

Erdemir, Y. (2015). Ebeveyninde Depresyon Olan veya Olmayan Çocukların Sosyal Uyum Açısından Karşılaştırılması. Yüksek Lisans Tezi, Beykent Üniversitesi, İstanbul.

Grissom, J. B. (2004). Age and Achievement. Educatıon Polıcy Analysis Archives, 12 (49), $1-41$.

Gündüz, F.,\& Çalışkan, M. (2013). 60-66, 66-72, 72-84 Aylık Çocukların Okul Olgunluk ve Okuma Yazma Becerilerini Kazanma Düzeylerinin İncelenmesi. International Periodical For The Languages, Literature and History of Turkish or Turki, 8(8), 379-398.

Güngören, D. (2011). Evlilik Çatışmasının Okul Öncesi Eğitim Kurumuna Devam Eden 5-6 Yaş Çocuklarının Sosyal Uyum ve Becerilerine Etkisi. Yüksek Lisans Tezi. Maltepe Üniversitesi, İstanbul.

Gürsakal, S. (2012). Pısa 2009 Öğrenci Başarı Düzeylerini Etkileyen Faktörlerin Değerlendirilmesi. Süleyman Demirel Üniversitesi İktisadi ve İdari Bilimler Fakültesi Dergisi, 17(1), 441- 452.

Hamarata, E. (2004). Üniversite Öğrencilerinin Yakın İlişkilerindeki Bazı Değişkenlerin (Benlik Saygısı, Depresyon ve Saplantılı Düşünme) Bağlanma Stilleri Açısından İncelenmesi. Doktora Tezi, Selçuk Üniversitesi, Konya.

Huges, M.,Pinkerton, G., \& Plewis, I. (1979). Children's Difficulties on Startıng Infant School. Association for Child Psychology' and Psychiatry, 187- 196.

Işık, M. (2007). Anasınıfina Devam Eden Beş-Altı Yaş Çocuklarına Sosyal Uyum ve Beceri Ölçeğinin Uyarlanması ve Uygulanması. Yüksek Lisans Tezi.

Ikiz, F. E., \& Cakar, F. S. (2010). Perceived Social Support and Self-Esteem in Adolescence. Procedia-Socialand Behavioral Sciences, 5, 2338-2342.

İlköğretim ve Eğitim Kanunu (2012). Resmî Gazete. Yayım Tarihi: 30.03.2012. Sayısı: 10705. Numaras1: 222.

Kabasakal, Z. \& Çelik N. (2010). Sosyal Beceri Eğitiminin İlköğretim Öğrencilerinin Sosyal Uyum Düzeylerine Etkisi. İlkögretim Online, 9 (1), 203-212.

Kahramanoğlu, R., Tiryaki, E., \& Canpolat, M. (2014). İlkokula Yeni Başlayan 60-66 Ay Grubu Öğrencilerin Okula Hazır Oluşları Üzerine İnceleme. Kastamonu Üniversitesi Kastamonu Ĕ̆itim Dergisi, 23(3), 1065- 1080.

Kalyencioğlu, D.,\& Kutlu, Y. (2010). Ergenlerin Aile İşlevi Algılarına Göre Uyum Düzeyleri. İstanbul Üniversitesi Florence Nightingale Hemşirelik Dergisi, 18(2), 56-62.

Kandır, A.,\& Orçay, M. (2011). Beş-Altı Yaş Çocuklarının Erken Öğrenme Becerileri İle Sosyal Uyum Ve Becerilerinin Karşılaştırmalı Olarak İncelenmesi. İlköğretim Online, 4050.

Kapçı, E.G., Artar, M., Avşar, V., Daşcı, E. \& Çelik, E.G. (2015). İlkokula Beş ve Altı Yaşında Başlayan Çocukların Ruhsal ve Sosyal Gelişim ile Akademik Benlik Algıları Açısından Karşılaştırılması. Ankara Üniversitesi Eğitim Bilimleri Fakültesi Dergisi, 48(2).

Karasar, N. (2014). Bilimsel Araştırma Yöntemi. (26. Baskl). Ankara: Nobel Yayıncılık.

Karataş, Z. (2012). Eğitim Fakültesi Öğrencilerinin Empatik Becerileri ve Benlik Saygısı Düzeylerinin İncelenmesi. Mehmet Akif Ersoy Üniversitesi Eğitim Fakültesi Dergisi, 12(23), 97-114. 
Karayılmaz, D. (2008). Ana Sinıfina Devam Eden Çocukların Duygusal Zeka ve Sosyal Uyum Becerileri Arasındaki Ilişskinin İncelenmesi. Yüksek Lisans Tezi. Gazi Üniversitesi, Ankara.

Kartal, H. ,Bolattekin, Y. \& A. Bilgin (2016). The Importance of Early Childhood Education and School Starting Age in the Reading-Writing Learning Process. Participatory Educational Research, 3(1), 79- 101.

Kawaguchi, D. (2011). Actual Age at School Entry, Educational Outcomes, and Earnings. J. JapaneseInt. Economies, 25, 64-80.

Kurt, F. (2007). Okul Öncesi Kurumlara Devam Eden Beş Altı Yaş Çocuklarının Sosyal Uyum ve Becerilerine Proje Yaklaşımlı Ĕgitim Programlarının Etkisinin İncelenmesi. Yüksek Lisans Tezi. Gazi Üniversitesi, Ankara.

Langer, P., Kalk, J. M., \& Searls, D. T. (1984). Age of Admission and Trends in Achievement: A Comparison of Blacks and Caucasians. American Educational Research Journal, 21(1), 61-78.

Lian, T. C. (2008). Family Functioning, Perceived Social Support, Academic Performance And Self-Esteem. Pertanika Journal of Social Sciences and Humanities. 16 (2) 285-299.

MEB (2014). İlköğretim Kurumları Yönetmeliği. Http://Mevzuat.Meb.Gov.Tr/Html/ilkveokuloncyon_0/ilkveokuloncyon_0.html. İndirilme Tarihi: 30.05.2016.

Merter, F., Şekerci, H., \& Bozkurt, E. (2014). Aynı Sınıfta Öğrenim Gören Altmış Altı ve Yetmiş İki Aylık Öğrencilerin Yaşadığı Sorunların Öğretmen Görüşlerine Göre Değerlendirilmesi. 12. Uluslararası Sinıf Öğretmenliği Sempozyumu, (s. 87-98). Aydın.

Oktan V. \& Şahin, M. (2010). Kız Ergenlerde Beden İmajı İle Benlik Saygısı Arasındaki İlişkinin İncelenmesi. Uluslararası İnsan Bilimleri Dergisi, 7(2), 543- 556.

Pişkin, M. (1996). Self-Esteem, Locus of Control and Academic Achievement of Secondary School Children both in England and Turkey. Yayınlanmamış Doktora Tezi. University of Leicester, Faculty of Education and Continuing Studies. (İngiltere).

Pişkin, M. (1997). Türk ve İngiliz Lise Öğrencilerinin Benlik Saygısı Yönünden Karşılaştırılması. III. Ulusal Psikolojik Danışma ve Rehberlik Kongresi Bilimsel Çalışmaları, Kongre Kitabı. Adana: Ç.Ü. Eğitim Fakültesi Rehberlik ve Psikolojik Danışma Anabilim Dalı ve Psikolojik Danışma ve Rehberlik Derneği Yayını.

Plummer, D. M. (2011). Benlik Saygısı Çocuklarda Nasıl Geliştirilir? (1. Baskı). (E Aksay, Çev.). İstanbul: Sistem Yayıncılık.

Sarıkaya, A. (2015). 14-18 Yaş Arası Ergenlerin Benlik Saygısı ve Psikolojik Dayanıklılık Düzeyleri Arasındaki İlişki. Yüksek Lisans Tezi, İstanbul Bilim Üniversitesi, İstanbul.

Seçer, İ., İlbay, A. B., Ay, İ., \& Çiftçi, M. (2012). Yatılı İlköğretim Bölge Okullarındaki Öğrencilerin Benlik Saygılarının İncelenmesi. Sakarya University Journal of Education, 1(3), 61-73.

Serebryakova, T. A., Morozova, L. B., Kochneva, E. M., Zharova, D. V., Skitnevskaya, L. V. \& Kostina (2016). The Problem of Socio-Psychological Adjustment of Personality in the Scientists' Studies. International Journal of Environmental \& Science Education, 11 (11), 4706-4715.

Sungur, G. (2010). Illkögretim Birinci Sinıfa Devam Eden Çocukların Sosyal Uyum ve Becerilerinin Incelenmesi. Yüksek Lisans Tezi. Selçuk Üniversitesi, Konya.

Sungur, O. (2016). Korelasyon Analizi. Ş. Kalayc1, (Ed.), SPSS Uyguamalı Çok Değiş̧kenli Istatistik Teknikleri (7. Basım) içinde (116- 125). Ankara: Asil Yayıncılık. 

2012-2013 Between 60-66 Months and Over 66 Months

Tapmaz, Ç. (2012). Halk Oyunları Çalışmalarının İlköğretim Beşinci Sinıf (10-11 Yaş Gurubu) Ögrencilerinin Sosyal Uyum Düzeylerine Etkisi Üzerine Bir İnceleme. Yüksek Lisans Tezi. Balıkesir Üniversitesi, Balıkesir.

Tutal, Ö. (2013). İlk Okuma-Yazma Öğrenmede Okula Başlama Yaşının Okuma-Yazma Başarısına Etkisi. Yüksek Lisans Tezi. (B. Oral, Dü.) Diyarbakır.

TÜİK. (2017). Evlilik ve Boşanma İstatistikleri. Nüfus ve Vatandaşlık Işsleri Müdürlüğü Haber Bülteni, 26642.

Türedi, E. (2015). Özyeterlik, Benlik Saygısı Ve Atılganlık Düzeyi İlişkisi -Cinsiyet ve Deneyim Süresi Açısından Resmi Okul Ve Özel Okul Öğretmenleri Üzerine Bir Araştırma. Yüksek Lisans Tezi, Toros Üniversitesi, Mersin.

Uğurlu, F. M. (2012). Üniversite Öğrencilerinin Sportif Faaliyetlere Katıllm Düzeyi İle Sosyal Uyum Ve Iletişim Becerilerinin İncelenmesi. Yüksek Lisans Tezi. Gaziantep Üniversitesi, Gaziantep.

Uz- Baş, A. (2003). İlkögretim 4 ve 5. Sinuflarda Okuyan Öğrencilerin Sosyal Becerileri ve Okula Uуити ile Depresyon Düzeyleri Arasındaki İlişkinin İncelenmesi. Doktora Tezi. Dokuz Eylül Üniversitesi Eğitim Bilimleri Enstitüsü, İzmir.

Ünlü, F. (2015). Ebeveyni Boşanmış Bireylerde Benlik Saygısı, Yalnızlık ve Bağlanma Stilleri Arasındaki İlişkinin İncelenmesi. Yüksek Lisans Tezi, Haliç Üniversitesi, İstanbul.

Yavuzer, H. (2003). Ĕgitim ve Gelişim Özellikleriyle Okul Çă̆l Çocuğu. (9. Baskl). İstanbul: Remzi Kitapevi.

Yavuzer, H. (2004). Ana- Baba ve Çocuk. (17. Baskl). İstanbul: Remzi Kitapevi.

Yeğen, B. (2008). Ortaöğretim Öğrencilerinin Sosyal Uyumları İle Saldirganlık Düzeyleri Arasındaki İlişkinin İncelenmesi (Kadıköy İlçesi Örneği). Yüksek Lisans Tezi, Yeditepe Üniveristesi, İstanbul.

Yelsma, P.,\& Yelsma, J. (1998). Self-Esteem and Social Respect Within The High School. The Journal Of Social Psychology, 138(4), 431-441.

Yılmaz, S., \& Ekinci, M. (2001). Hemşirelik Yüksekokulu Öğrencilerinde Benlik Saygısı ve Atılganlık Düzeyi Arasındaki İlişki. Journal of Anatolia Nursing and Health Sciences, 4(2), 1-10.

Yılmaz, E \& Tepeli, K. (2013). 60-72 Aylık Çocukların Sosyal Problem Çözme Becerilerinin Duyguları Anlama Becerileri Açısından İncelenmesi. Türkiye Sosyal Araştırmalar Dergisi, 17(2), 117-130.

Yücel, Y. (2013). Ortaokul Öğrencilerinin Algıladıkları Anne-Baba Tutumlarının, Benlik Saygısı ve Öğrenilmiş Çaresizlik Ille İlişkisi. Yüksek Lisans Tezi, Arel Üniversitesi, İstanbul. 